\title{
Uprooted: Identity and illegality among return migrants in Mexico
}

\author{
Heidy Sarabia*
}

\section{Recepción: 5 de abril de 2017 Aceptación: 29 de agosto de 2017}

Abstract Using a transnational lens, this article focuses on Mexican migrants who arrived in the U.S. as children and returned to Mexico as young adults, to show how state and national identities are shaped by the cultural and legal contexts of their reception in both the U.S. and Mexico. In the U.S., their national identity as Americans is accomplished through the process of socialization, but their state identity is shaped by their legal status as unauthorized migrants. In Mexico, their state identity is informed by their status as citizens, but their national identity is complicated by their lack of knowledge of Mexican culture. Ultimately, the migration experience and their disjointed national and state identities, both in the U.S. and in Mexico, shape the migrants' experiences of reincorporation into Mexico as Americanized Mexicans. This article draws on in-depth interviews and participant observation collected in the border town of Mexicali, Baja California, Mexico, between July 2009 and August 2010.

KEY WORDS: return migrants, Mexico, illegality, citizenship, identity.

Resumen Este artículo analiza las experiencias de migrantes mexicanos que llegaron como niños a los Estados Unidos, pero regresaron a México como adultos jóvenes, y muestra cómo las identidades estatales y nacionales son moldeadas por los contextos culturales y legales de recepción tanto en los Estados Unidos como en México. En los Estados Unidos, su identidad nacional como "americanos" se logra a través del proceso de socialización, pero su relación con el estado es determinada por su estatus legal. Mientras que, en México, su relación con el estado es informada por su condición de ciudadanos, pero su identidad nacional es complicada por su falta de conocimiento de la cultura mexicana. Las identidades nacionales y estatales fragmentadas, tanto en Estados Unidos como en México, configuran las experiencias de reincorporación de estos migrantes como "mexicanos americanizados" en México. Este artículo se basa en entrevis-

\footnotetext{
*Asistant profesor -Department of Sociology, California State University Sacramento, h.sarabia.r@gmail.com
} 
tas y observaciones recogidas en Mexicali, Baja California, México, entre julio de 2009 y agosto de 2010.

PALABRAS CLAVE: Migrantes retornados, México, ilegalidad, ciudadanía, identidad.

\section{Introduction}

\section{Tater}

acinto, a 21-year-old man living on the U.S.-Mexico border in Mexicali, Baja California, Mexico, arrived in the U.S. with his parents as an 8-month-old baby and lived there for 20 years. Once he turned 18 in the U.S., Jacinto realized that he was undocumented: he could not legally drive, hold a job, or attend school. He felt as if he couldn't do anything, that he was "too encerrado [caged]." "Due to the many limitations Jacinto faced in the U.S., he decided to return to Mexico. ${ }^{2}$ Now, living in Mexico, on the other side of the border, he feels happier because he has more rights, but he is also alone. His immediate family-his parents, a brother, and a sister-stayed in the U.S., and, although Jacinto talks to them daily on the phone, he still misses the daily interactions. He reminiscences, "[I miss] hugging them, kissing them. When we were together in the U.S. we would come home at night and watch TV, eat, we were always together, all three siblings, talking, chattering. We would talk to my dad, we would always talk to my dad, we had good communication, we had a great relationship." Jacinto enjoys the fact that he is a citizen in Mexico and has the rights he did not have in the U.S., but feels that his life is incomplete because he is separated from his immediate family.

Jacinto's story of return migration highlights that in the U.S. he felt "at home" but was legally marginalized (as an undocumented immigrant). As a resident of Mexico he enjoys being a formal citizen, but does not feel at home because his family is not with him. This article focuses on the experiences of young migrants who, like Jacinto, migrated from Mexico to the U.S. and developed attachments there, but then returned to Mexico, separating from the connections forged in the U.S. The article sheds light on how migrants challenge and are challenged by nation-state boundaries of legal and emotional belonging and attachments. I explore two questions: How does migration and return migration shape the identities and experi-

Unless otherwise stated, all quotes in the paper are from personal interviews conducted by the author.

2 I collected data from 2009 to 2010, two years before the Deferred Action for Childhood Arrivals (DACA) memorandum was signed by President Obama's Secretary of Homeland Security on June 15, 2012, allowing immigrants who entered the U.S. as children (and who met other criteria) to attain a work permit and be exempt from deportation. But DACA does not provide these immigrants with permanent legal status, as they must renew the permit every two years. Moreover, with the election of Donald Trump to the presidency in 2016, the future of DACA is uncertain. 
ences of national and state memberships among young migrants? And, in particular, how does unauthorized migration to the U.S. shape identities and memberships among migrants in the U.S. and Mexico?

This paper sheds light on the experiences of return migrants, those who left the U.S. at a time when migrants were more likely to be deported, but before the U.S. enacted the Deferred Action for Childhood Arrivals (DACA) policy. While today there are far fewer young migrants who return to Mexico on their own, the U.S. government continues to deport migrants to Mexico. Therefore, research on those who return to Mexico continues to be an important item on the agenda for understanding the resettlement experiences of young migrants who leave their homeland as children and return as adults.

\section{Fluid identities and rigid states}

This article brings together three topics in the literature that addresses mobility: the decoupling of the nation-state, the legal and cultural productions of illegality, and the experiences of return migration. In the end, using the experiences of 17 young return migrants in Mexico, I show the ways in which the current era of mass mobility continues to be strongly shaped by the state.

\section{The decoupling of the nation-state}

The movement of people, especially of migrants, is embedded within other flows across society, such as those of money, ideas, information, and technology (Appadurai, 1996b). This growing interconnectedness has resulted in a growing permeability of borders between countries, which has in turn diminished the nationstate's "capacity to generate policy instruments able to control the flow of goods and services, ideas and cultural products, etc." (Held, 1999, p. 93). This has prompted some scholars to announce the "end of the nation-state" (Ohmae, 1994). States have responded to these challenges by relinquishing their control in some areas (e.g., the economy) but asserting their sovereignty in others (e.g., national security). Specifically, scholars have argued that nation-states, rather than disappearing, are being decoupled and reconfigured (Andreas \& Biersteker, 2003).

Migration stands as an important force shaping this decoupling and reconfiguration of nation and state, as migrants change the connections between them (Sassen, 2003; Appadurai, 1996a; Brown, 2010; Brubaker, 1992). As migrants navigate the changing terrain of increasingly tenuous nation-state relationships, they often challenge both state territorial boundaries and national identity boundaries. 
For example, on the one hand, unauthorized migrants often cross state boundaries without permits, openly challenging the efforts by states to control people's movements. On the other hand, their insertion and settlement into a new society also challenges their understandings of national identity and belonging, thus bringing to the surface anxieties about national cohesion.

National and state memberships often overlap, but not always. First, state membership is shaped by the rules of the state, which determine who belongs legally. Thus, we can associate state and legal as features of formal citizenship-the "official" membership in a community. This form of belonging is mostly legal and political, but has concrete consequences for cross-border and transnational practices. Second, beyond the legalistic definition of the state, national identity and community membership highlight the ways in which an "imagined community," as Benedict Anderson (1983) called it, is formed. Thus I highlight the socialization process by which people imagine themselves as belonging to the national group regardless of their legal status. This form of belonging is mostly social and cultural, but with specific consequences for persons participating in cross-border and transnational practices. By comparing nation and state membership, belonging, and citizenship in both the U.S. and Mexico, I take a transnational approach that seeks to highlight the experiences of return migrants in both the U.S. and Mexico.

In addition to physically crossing international borders, migrants forge economic, cultural, and social ties across them as well. Scholars of migration have recently turned their focus to the connections migrants often maintain between their homelands and the migratory countries of destination, highlighting the ways in which migrants straddle social, political, and cultural ties between two or more societies (Glick-Schiller, Basch \& Szanton-Blanc, 1994; Levitt, 2001; Waldinger, 2008). Yet research into migratory flows usually assumes a move from the homeland to the host society by adult migrants who idealize the homeland and, in this context, create transnational ties that allow them to remain connected to their homeland. Scholars have shown that transnational practices among these adult migrants actually allow them to maintain ties to their homeland and simultaneously be inserted into the host society (Levitt, 2001). But less is known about the transnational practices and national attachments of migrants who move as children, or return migrants who have spent long periods of time away from their homeland, and how legal status shapes these transnational practices (Sarabia, 2011). In addition, the literature tends to focus on mobility and often ignores the ways in which states shape mobility and thus national belonging. 


\section{Legal and cultural productions of illegality in the context of decoupling}

Given the size and scope of global undocumented migration, scholars have increasingly focused on the way in which the state defines membership through legal definitions of belonging. Thus, the way in which the state, through the law, creates a status and an identity for undocumented migrants outside the sanction of the law through illegality (DeGenova, 2002) has become central to the understanding of undocumented immigrants' experiences. While illegality is a "political identity" (DeGenova, 2002, p. 422) defined by the state and the law, it is also a social and cultural process. In the context of the decoupling of the nation-state, the state legally defines illegality, but national membership also shapes-culturally and socially-the meanings of illegality. Ngai (2005), for example, argued that illegality is not just a legal category, but can also encompass those suspected of not being citizens-such as Asian-American and Latino citizens in the U.S., who are often viewed as "alien citizens." By defining the boundaries of who legitimately belongs as a citizen, the social field expands to include those who are socially viewed as outsiders regardless of their legal status. Moreover, as a social process, illegality is also a learned experience. Gonzalez (2011), for example, showed the process of the "transition to illegality" as undocumented children become adults in the U.S., and Abrego (2011) showed how different institutions (workplaces and schools) socialize undocumented immigrants differently. Yet how the relationship of individuals to the state and illegality changes as migrants cross borders remains understudied.

Given that illegality is both a political and a social process, context matters. Rosas (2006), for example, showed that along the U.S.-Mexico border, undocumented migrants not only experience illegality (techniques of power exerted by the state and the law), but must also confront policeability-violence, surveillance, and management techniques exerted by other actors, such as vigilantes, smugglers, and muggers (Rosas, 2006). The work of Rosas highlights that illegality is not only produced by the state, it is also created in civil society by other actors. In other words, illegality must be understood in terms of peers, family, and those close to migrants, as well as vis-à-vis the state. Less is known about how illegality changes as migrants move between societies (say, from the U.S. to Mexico) or legal categories (say, from being an undocumented immigrant in the U.S. to being a legal citizen in Mexico).

\section{Return migration and the overarching consequences of illegality}

The scholarship on illegality has pointed out that illegality has intensified in recent years as more migrants in the U.S. are placed outside the law. This is partly due to the bureaucratic transfer of the Immigration and Naturalization Service from 
the Department of Justice to the Department of Homeland Security, and partly to legislative efforts to encompass more migrants under the umbrella of "criminal aliens" (Sarabia, 2011). This is the case even though the "crimes" for which migrants are convicted do not involve crimes against people, for the most part, but are mostly for "transgressions against the sovereign authority of the nation-state" (Ngai, 2005, p.175). Nevertheless, illegality encompasses everyday life, as routine activities become criminalized (Coutin, 2000). Yet the scholarship on illegality in the United States has focused mostly on the experiences of migrants living in the U.S., who are subject to state and legal definitions imposed by the U.S, and the ways in which they must live with and may internalize these state categories (Gonzales \& Chavez 2012). This literature suggests that if people leave a state in which they are categorized, treated, and viewed as illegal, the stigma and experience of illegality may vanish. Thus, this paper seeks to engage with this scholarship and advance our understanding of illegality by showing how illegality has long-term effects and repercussions beyond the confines of the U.S. (i.e., in Mexico).

DeGenova linked illegality to deportability, explaining that illegality is lived through a palpable sense of deportability - "the possibility of deportation." (DeGenova, 2004, p. 161). Deportability, the mere threat of being removed from the U.S., shapes life in the U.S. (DeGenova, 2002), and actual deportation disrupts family relations, ties, remittance behavior, and settlement experiences (Eschback et al., 1999). A deportation, after all, could become a major life event for migrants settled in a host society. We know, for example, that deportation can have serious consequences for migrants, as return migrants show "higher prevalence of heart disease, emotional/psychiatric disorders, obesity, and smoking than non-migrants" (Ullmann, Goldman \& Massey, 2011). However, returning to their homeland, on their own or through forced deportations, is not a uniform experience, as it is shaped by factors such as how prepared migrants are for their return and to what extent they are able to mobilize resources in their favor upon their return (Cassarino, 2004), as well as the context of their reception. For example, Cobo, Giorguli, and Alba (2010) found that while migration to the U.S. increases the likelihood of upward mobility relative to nonmigrants, "In Mexico ... [return] migration is generally associated with a lower likelihood of upward mobility, irrespective of the age at which it began" (p. 260), and returning specifically to a high-poverty area is associated with a lower likelihood of upward mobility in Mexico (p. 262). Likewise, Gitter, Gitter, and Southgate (2008) found that migration has a negative impact on employment probabilities for return migrants residing on the northern Mexican border. All these perspectives, however, have focused on the experiences of adult migrants, and we know little about the return experiences of individuals who migrated as children.

Undocumented youth in the U.S. are socialized as U.S.-Americans, but racialized as "other." Research on children who grow up in the U.S. and are then deported 
to their homeland as criminals has tended to portray a bleak outcome, because of the context in which the reception gang-affiliated migrants occurs as their criminality becomes extra-territorial. That is, U.S. criminalizing definitions of migrants follow them upon their return to their homeland (Miller, 2011). Yet in the current context of mass deportations, we know that most deportees are not criminals, and we still know very little about those socialized in the U.S. who return to their homeland as voluntary returnees or deported migrants. While scholars have also shown that age and generation influence the experience of illegality, shaping how people respond to and adapt to the categories of illegality (Gonzales \& Chavez, 2012; Abrego, 2011), less is known about the consequences of these experiences when young migrants return to their homeland.

This article makes three important contributions to the literature on the decoupling of nation-states, illegality, and return migration. First, it highlights the ways in which mobility and the decoupling of the nation-state take place as everyday lived experience, among young return migrants in Mexico-who experience mobility in a limited way, given that they are not legally allowed to move back and forth between Mexico and the U.S. Thus, their experiences highlight that the territorial state remains an important player in shaping how the decoupling of the nationstate is experienced by migrants. Second, the article highlights the legal, social, and cultural consequences of illegality beyond state territorial boundaries, and as migrants move from one national context to another, showing how national and state memberships shape the experiences of illegality among young migrants as they move from Mexico to the U.S. and then return from the U.S. to Mexico. Finally, by focusing on the experiences of return migrants in Mexico, I show the way in which the relational aspect of illegality changes as these migrants relate to the Mexican state and their Mexican peers, but will also use the context of their experiences of illegality in the U.S. to show some of the long-term and long-distance effects of living undocumented in the U.S.

\section{Return migrants}

In this article, I focus on the experiences of 17 return migrants who had previously lived in the U.S. and, at the time of the interviews, were living on the U.S.-Mexico border in the city of Mexicali, Baja California, Mexico. ${ }^{3}$ When I conducted the in-

These interviews are part of a larger research project on the U.S.-Mexico border, where 60 people living in the border city of Mexicali were formally interviewed. The interviews were analytically classified according to the interviewee's legal relationship to the U.S. as an "inadmissible" return migrant or as a "nonimmigrant" border crosser. In this article I focus on the experiences of "inadmissible" return migrants, as I have focused elsewhere on the experiences of "nonimmigrant" border crossers (Sarabia, 2014). 
terviews, during the period from June 2009 to August 2010, all 17 return migrants were living in Mexico. Each interview lasted from one to three hours. I focused on migrants who had lived in the U.S. for a significant period of time, were exposed to socializing institutions in the U.S. (mostly schools), and had recently returned to Mexico. Given this focus, most of the interviews were conducted in English, some were conducted both in English and in Spanish, with Spanglish sprinkled throughout the interview, and a few were conducted in Spanish. In addition, to highlight the extensive socialization process to which these migrants had been exposed in the U.S., at the time of the interviews most of them were working in bilingual settings. Thirteen interviewees worked at a calling center that hired bilingual workers, three worked at a tourism-related agency that also hired bilingual workers, and one interviewee was unemployed. Scholar Jill Anderson has shown that these calling centers often offer the bilingual return migrants a place to feel safe, build community, and develop economic stability (Anderson, 2015).

The circumstances under which these migrants had returned to Mexico varied. Some of them had been officially deported by the U.S. government, while others had signed voluntary departures to avoid long legal proceedings. Still others had returned to Mexico on their own. Most interviewees (11) who returned to Mexico voluntarily reported various reasons-they were brought back by their parents, they returned due to a lack of jobs in the U.S., or they returned to apply for legal residency in the U.S.-while the rest (6) reported being deported by the U.S. government through an official process of removal. Nevertheless, once in Mexico all shared the same legal status vis-à-vis the U.S., namely, once in Mexico they became "inadmissible" for entering the U.S. legally. This restrition on admissibility meant that they were legally banned from returning to the U.S. The length of the restriction ranged from 5,10 , or 20 years to life, depending on their individual cases. Given such a ban-even on applying to return legally to the U.S.-journalist and activist Nancy Landa wrote a letter to President Obama in 2012 asking him to remove the "10-year ban for deportees so they can successfully appeal their cases," and "to allow "deportees who are working in their country of origin and are required to travel to the U.S. for business purposes" to obtain nonimmigrant visas, but her demands have gone unheeded (cited in Truax, 2015, p. 75).

In this category of "inadmissible," I interviewed mostly single individuals (12 single, 4 married, 1 divorced), 9 women and 8 men, with an average age of approximately 24 . The average age of migration to the United States was a little more than 11-some had migrated as young as 8 months old, while others migrated as adults at 21 . I included all of these individuals in this category because they shared a common experience of being socialized in the U.S., feeling Americanized, speaking English, and feeling uprooted in Mexico. Even those who had migrated as young adults had the experience of being socialized and inserted into the social fabric of 
the U.S. These experiences sharply contrast with those of individuals who often visit the U.S. but do not develop deep emotional and affective ties there (Sarabia, 2014). The average number of years of living in the U.S. was 11, and the average age of return to Mexico was approximately 21. Finally, the average number of years of living back in Mexico was a little more than 2 .

TABLE 1. Summary Data of "Inadmissible" Interviewees ( $\mathrm{N}=17)$

\begin{tabular}{lrrrc}
\hline & Average & Median & Range \\
\hline Age at the time of interview & 24.4 & 25 & {$[18-36$ years $]$} \\
Age of migration to the U.S. & 10.2 & 7.5 & {$[8$ mo-21 years $]$} \\
Number of years living in the U.S. & 11 & 12 & {$[3-22$ years $]$} \\
Age at time of return to Mexico & 21.5 & 21 & {$[10-34$ years $]$} \\
Number of years living back in Mexico & 2.5 & 2 & {$[6$ mo- 9 years $]$} \\
Years of education & 12.5 & 12 & {$[9-16$ years $]$} \\
\hline
\end{tabular}

Uprooted Migrants: Cultural Citizenship and Legal Belonging in the U.S. and Mexico

The rest of the paper is organized in three sections that demonstrate how nationstate memberships and attachments are decoupled for migrants who are born in Mexico, move to the U.S., and then return to Mexico. First, I briefly discuss how socialization in the U.S. is key to understanding the reintegration experiences of these return migrants in Mexico. That is, while in the U.S., the migrants became socialized and acculturated into the nation, but they also remained legally marginalized as unauthorized migrants, unable to enjoy the same rights as their documented peers. In the U.S. context, their state membership was shaped by their legal marginality. In the second part, I show how their experiences of illegality in the U.S. shaped their experiences in Mexico. In Mexico they appreciated their legal standing (as Mexican citizens) with rights that they were explicitly denied in the U.S. But this legal standing was minimized by their cultural alienation from a nation they did not completely identify with. In other words, they were legal citizens but felt like cultural outcasts because they felt like outsiders in Mexico. In the Mexican context, these migrants compared their experiences as formal citizens in Mexico and as legal outsiders in the U.S., to appreciate their rights in Mexico as formal citizens. In the third and final section, I describe how these return migrants' aspirations for the future were shaped by their experiences in both the U.S. and in Mexico. They wished to return to the U.S., the place they considered their "home," but they 
did not want to return unauthorized. They did not want to be legally marginalized again. In sum, for these return migrants, integration into their homeland (Mexico) became an arduous process, shaped by their experiences of illegality in the U.S, and thus highlighting the long-term and long-distance effects of experiencing illegality in the U.S.

TABLE 2. Summary of Argument about the Legal and Socio-cultural Membership of Return Migrants in Mexico

\begin{tabular}{|c|c|c|c|}
\hline & & \multicolumn{2}{|c|}{ Context } \\
\hline \multirow{4}{*}{$\begin{array}{l}\text { Membership } \\
\text { and identity }\end{array}$} & & In the U.S. & In Mexico \\
\hline & State (legal) & $\begin{array}{l}\text { Blocked membership due } \\
\text { to legal marginalization } \\
\text { as undocumented } \\
\text { immigrants }\end{array}$ & $\begin{array}{l}\text { Formal citizen rights } \\
\text { but delayed incorporation } \\
\text { due to lack of knowledge } \\
\text { of culture and institutions }\end{array}$ \\
\hline & & & \\
\hline & $\begin{array}{c}\text { National } \\
\text { (socio-cultural) }\end{array}$ & $\begin{array}{l}\text { Cultural belonging } \\
\text { due to socialization } \\
\text { and acculturation as } \\
\text { U.S.-Americans }\end{array}$ & $\begin{array}{l}\text { Culturally dislocated } \\
\text { due to lack of language } \\
\text { and cultural knowledge } \\
\text { of Mexico; Americanized } \\
\text { Mexicans }\end{array}$ \\
\hline
\end{tabular}

\section{Mexican-Americans: Cultural Citizens and Legal Outcasts in the U.S.}

In this section I show how national and state memberships are split in the U.S. On the one hand, migrants who arrived at a young age became national members of the U.S. through the process of socialization (mostly in the school system) and also in the context of ethnic communities (Mexican communities in the U.S.). In the U.S. context, these migrants are nationalized as racialized bodies. The experiences of these migrants as racial minorities in the U.S. shapes their identity as "MexicanAmericans," that is, "Americans" of Mexican descent. On the other hand, their legal status as undocumented immigrants prevented their complete incorporation, and their relationship to the state and state actors reminded them of their legal marginality. Thus, their experiences of illegality were shaped by legal marginality and their apparent inability to do what their documented peers were able to to-drive, work, and study with the sanction of the state.

Citizenship and membership are not only legal and political, but also social processes (Marshall, 1964), developed through social relationships. Migrants who leave their homeland as children often do not develop their citizenship and membership in relation to their official homeland, but in the context of the host society 
in which they grow up. Migrants who leave their homeland as children often have few memories of the "home" left behind. Xavier, for example, explains how little he remembers of Mexico before he migrated to the U.S.: "I was too small to remember Mexico." They are migrants who often have no relationship with their homeland.

It was difficult to live in the U.S. without any documents, but living among family and friends created a sense of home and community, albeit a racialized experience as Mexican immigrants in the U.S. Xavier, for example, explains that in the context of the U.S., comparing himself with white Americans, he identified himself mostly as "Mexican." He explains,

...when I was there [in the US] I identified much more like Mexican because there, there are a lot of güeros [white people], and that is why, but I would always hang out with Mexicans.

In the context of the U.S., where he would compare himself to the majority population (Anglo), Xavier identified himself as Mexican. In the U.S., his skin color and background shaped his identity as Mexican. Since identity is formed in the context of relationships, migrants, too, determine which groups they belong to through a social comparison process (Burke \& Stets, 2000, p. 225). In the U.S., these migrants were not incorporated in neutral terms, but as "Mexicans" and racial "others." Nevertheless, they felt a sense of home and belonging in their community.

The socialization process, by which these children learned the language, culture, and history of the U.S., is often rapid and absolute. In fact, many return migrants expressed that they had almost lost their first language (Spanish) while living in the U.S. In the U.S. they were culturally Mexican but also American. These migrants' experiences in schools assured their socialization into U.S. culture. Thus, they felt they belonged culturally as Mexican-Americans, but legally they could not belong to the nation-state. Their legal marginality and the stigma of their undocumented status was a constant reminder of their outsider status. As Felipe explains,

The only thing that I hated [in the U.S.] were the cops and migration officers because they are a bunch of assholes. That is the only thing I hate. Everything else, people, everything, I am cool with everyone.

As Felipe highlights, his social connections made him feel welcome in the U.S., but his relationship to state actors (i.e., cops) reminded him of his legal vulnerability.

Moreover, comparing their experiences to those of their documented peerswho could do things like drive, work, and go to school with the sanction of the state-reminded these migrants of their legal marginality. Xavier, for example, ex- 
plained how he realized the limitations he had as a result of his unauthorized status in the U.S.:

The most difficult part of living undocumented in the U.S. was not being able to get the job you are qualified to get, the one you want, the one you are qualified to do, and you know you can do it and be able to earn more money. But only because you do not have documents, you cannot risk to start at a job like that, undocumented.

Not having the legal permits became a clear barrier for Xavier, who could obtain jobs only in the informal sector. For Xavier, not having legal status became a clear sign of his legal marginality and an apparent limit to his goals and dreams.

In addition to their legal marginality, the state also shaped the transnational practices of these migrants. Given their legal status in the U.S., the migrants could not engage in transnational practices and often lost touch with their Mexican families, roots, traditions, and even language. This solidified their socialization into U.S. society. Lorenzo, for example, was born in Mexicali, but was taken to the U.S. at the age of 5. Because he was undocumented in the U.S., he did not return to Mexico in the 22 years he lived in the U.S. When Lorenzo was deported to Mexicali, he did not even know how to get to his house:

I don't know anywhere here, what I can say is that I have never been to Mexicali before. You can say, even now, that I only know what is two miles north, two miles west, two miles east, two miles south of my house. I don't know anything beyond that. If it wasn't for my uncle that took me to my house, I wouldn't have been able to get to my house.

Not only did he not know how to find his home once he was back in Mexico, even after being in Mexico for a while, Lorenzo still had not explored beyond a small parameter outside of his house. This was due in part to the shock of being back in a place that felt foreign to him.

In sum, migrants who move to the U.S. as children become embedded in specific communities in the U.S.-mostly immigrant communities-facilitating their incorporation into the social fabric of the nation. Nevertheless, while they are socially incorporated into the web of the community, they still feel the legal marginality of being undocumented. Their incorporation into the social fabric, therefore, is fragmented: They are culturally Mexican-American (speaking English, learning the national history, building community), while simultaneously being legally marginalized as undocumented immigrants. Scholars have documented the experiences of migrants who arrived in the U.S. at a young age-also known as the 1.5 or 1.75 generation (Rumbaut, 2004; Abrego, 2011; Gonzales \& Chavez, 2012)-showing how these children must "learn to become illegal" in the U.S. (Gonzalez, 2011). Less is 
known about the experiences of these migrants once they return to their homeland. In the next section, I explore the experiences of these return migrants as they reintegrate into their homeland, Mexico.

\section{Americanized Mexicans: legal citizens and cultural outcasts in mexico}

In this section I show how the experiences of illegality in the U.S. shape these migrants' incorporation upon their return to Mexico, their official homeland. That is, given the legal marginality they experienced in the U.S., they become appreciative of the legal rights they enjoy as formal citizens in Mexico. Yet, given their socialization in the U.S., they also feel like cultural outsiders in Mexico-and, therefore, like "alien citizens."

Migrants who cross borders as children, usually between 5 and 14 years of age, are referred to as the 1.5 generation. While these children are first-generation migrants because they were born in another country, they are often socialized as second-generation migrants, given their socialization process in the host society during childhood. They are not completely comparable either to the first generation or to the second generation, because they are "pre-adolescent, primary-school-age children who have learned (or begun to learn) to read and write in the mother tongue at schools abroad, but whose education is largely completed here" (in the new country) (Rumbaut, 2006, p. 1167). The term "1.5 generation" seeks to capture the unique characteristics of these migrant children. For them, issues of state and national belonging are not well understood, and less is known about their experiences of return migration.

Given that these migrants crossed the border as children and have lived undocumented in the U.S., having formal citizenship rights-that is, being legal citizens-is often romanticized. Once these migrants return to their place of birth, they experience for the first time what it means to be a formal citizen, with full rights and privileges. For most migrants, their new citizenship status translates into a newfound freedom. For example, Monica explains, "[What I like most about Mexico is that] here I feel free and with more opportunities for me, since I am not from the U.S." Thus, Monica explicitly links her citizenship experiences of having more rights and feeling more freedom thanks to her legal status. In Mexico she is free because she is a Mexican citizen, while in the U.S. she was constrained because of her precarious legal status.

Unfortunately, for most returned migrants the newfound freedom is also accompanied by the reality of what the border represents: a rupture. Jacinto, for example, explains what he likes most about living in Mexico: 
More than anything else, that here, I do have my documents, I have an ID to vote, I have a driver license to drive my car, and I have a secure job. What I don't like is that I do not have my family with me, I am alone. All my friends, my family, they stayed there [in the U.S.], my parents, my brother and a young sister, all of them are there.

Jacinto makes explicit reference to the fact that as a Mexican citizen living in Mexico he has "documents." Yet his new citizenship does not afford him the ability to visit his family in the United States. Nevertheless, attaining and experiencing full citizenship is a significant new experience for these migrants. Jacinto further explains, "Now that I live in Mexico I feel more free... but in the U.S. I know more people and I have more friends... what I would like, is to be with my family." The new experiences of having legal rights is minimized by the reality of being away from family and friends in the U.S.

Mercedes also explains the conundrums of her current situation:

[I feel at home in Mexico because] in Mexico, I feel more free. But in the U.S. I feel more comfortable and protected in terms of security... [I feel like I belong] in the US...[I feel more connected] in Mexico.

As a formal citizen in Mexico, she feels the freedom she did not feel in the U.S. But in Mexico she has found other limitations that impede her flourishing-now she does not feel as safe as she did in the U.S. Research has found that the majority of return migrants in Mexico experienced grief, stress, and vulnerability due to the loss or separation from family, changes in social status, and physical or emotional risks (Moya, et al., 2016).

In the U.S., in the context of illegality, that is, state rejection and criminalization, immigrants reach beyond the formal definitions of citizenship and belonging to become part of their community. But membership encompasses more than just legal status. Thus, scholars have theorized citizenship beyond the formal rules of the state and the law. Bosniak (2000), for example, theorized citizenship broadly as rights, as practice, as identity, as status, and as activity. Under this conceptualization, citizenship is more than a legal status, as citizenship can develop not only from above (granted by the state) but also from below (through identity), as well as in different spheres (state or civil society), and in different domains (of family, kinship, or other primary relationships; Yuval-Davis, 1997). In fact, the state and its subjects often shape citizenship dialectically (Ong, 1996, p. 738). For example, Renato Rosaldo (1994) theorized cultural citizenship as the right to be different without compromising one's right to belong (p. 57). He showed that migrants enacted different forms of belonging (compared to the mainstream), and yet in the process created community and belonging (as a form of citizenship). Thus, citizenship and 
belonging become complicated in Mexico, where migrants are legal citizens but do not feel they belong to the fabric of the nation.

Not only do returned migrants find themselves separated from family and friends, and away from home, now they are in a place with fewer job prospects. Their personal legal status as citizens is now truncated by the structural reality of the job market in Mexico. Now they have the permits to gain lawful employment, but there are fewer jobs available. Xavier expresses the same feeling of freedom but laments the lack of jobs:

What I like best here [in Mexico] is that I am free, here I can drive without having to worry, I have a license, I have a car, here I can get a job, even though it is not the one I want, but I can apply wherever I want, although it is more difficult to find a job, but right now, being here is better.

Freedom in their new circumstances is a theme that repeatedly came up for these migrants, who explicitly compared their experiences in the U.S. as undocumented and their experiences in Mexico as citizens. But their citizenship is truncated due to the structural lack of opportunities. Monica makes a further connection between her new-found freedom and her citizenship status, stating, "What I like most [about living in Mexico] is the freedom, because I am Mexican and I feel great, and what I don't like is that there are no jobs." She laments the lack of work opportunities in Mexico.

The incorporation of these return migrants into Mexico is also complicated by their lack of cultural knowledge-most of them, after all, grew up in the U.S. Children who migrated to the U.S. at a young age realize upon their return that they are strangers in their own birthplace. Xavier explains:

The most difficult [part about coming back to Mexico], I think is the language, Spanish. Even though I can talk and maintain a conversation, well, it is not too fluid, and I don't understand the culture. Here I don't understand the jokes or the references or the TV shows or characters. Yes, I guess the most difficult thing here is the Spanish [language].

Having a limited command of Spanish reveals their outsider status in Mexico, as return migrants socialized in the U.S.-a realization with personal and also social consequences. Speaking Spanish with an English accent reveals their outsider status to other Mexicans. Olivia, for example, explained to me that she does not belong either in the U.S. or in Mexico. In the U.S. she was considered Mexican (not American), which signaled her outcast membership. But in Mexico she is considered pocha (not Mexican), further solidifying her outcast membership. 
These migrants feel a new sense of membership-legal citizenship-upon their arrival in their homeland; yet they find that legal citizenship has its limits in Mexico, given their lack of cultural knowledge. Having lived their childhood or adolescence in the U.S., they were acculturated and socialized and developed national attachments there. Yet their legal status in the U.S. also meant they were not sanctioned by the state. Now, in Mexico, they are sanctioned by the state as Mexican citizens, but their attachments, identities, and alliances are ambiguous and inconsistent. In addition, the Mexican state does not have re-integration programs to allow these return migrants to become part of the Mexican state (Suárez, 2016). In sum, they might be Mexican citizens, but they often feel like U.S.-Americans. They feel Americanized but unable to travel to or live in the U.S.

\section{Uprooted migrants: impossible subjects in the homeland}

In this final section, I show how these migrants deal with the disruption of return. I highlight the contradictions of nation-state belonging in Mexico, as these migrants attempt to make sense of their identity and future in Mexico, where they enjoy their formal citizenship rights but also experience a deep sorrow due to the separation from family, friends, and the place they learned to see as home.

Ngai (2005) defines the impossible subject as "a person who cannot be and a problem that cannot be solved" (p.5). These migrants become "impossible subjects" because they are unable to have a sense of full membership in either the U.S. or Mexico due to the legal, social, and cultural contradictions their presence presents for nation-state membership. Acculturated in the U.S. but living in Mexico, they face tension as they experience feelings of belonging to one nation (the U.S.) but being forced to live in another state (Mexico). They are akin to the "alien citizens," also described by Ngai, as formal citizens by virtue of their birth but presumed foreign by the mainstream culture and sometimes by the state (p. 2). These migrants become "alien citizens" in Mexico due to their inability to fully feel part of the Mexican national imaginary. They resolve this tension by embracing their dual frames of reference.

In terms of identity, belonging, and attachments, most of these return migrants feel that they belong to both worlds. As Xavier describes,

Before I used to say that I was Mexican, but now that I am on this side [in Mexico] I can see that I am much more. [I am] Mexican-American, much more American than Mexican, and that is after I got here, I noticed a lot, and I saw that I knew more and that I felt more comfortable, knew more people and the language in the U.S. [more than in Mexico]... To be Mexican-American is to have that identity but to live in, to call, yes, I 
call the U.S. home because that is where I know everyone, where I live, well, used to live, and that is where I feel much more comfortable.

As Xavier explains, now, in the context of living in Mexico, he realizes how his migration experience in the U.S. changed him. Most of the migrants I interviewed used the term "Mexican-American" to describe their identity. Their descriptions highlight the decoupling of national-state membership-they are Mexican formal citizens but identify as culturally American. They are effectively describing an Americanized Mexican identity, that is, Mexican citizens who are culturally "American."

Jacinto, for example, explains how he identifies as Mexican-American culturally even though he is unable to live in the U.S.:

[I feel more identified] in the U.S., because over there, people are more open minded, because I lived in a small community [a ranch] and we all knew each other, and nobody would bother you.... [My home is] in the U.S., because my family and friends are over there, I grew up there and I feel home [there].... [I identify as] Mexican-American, but I am fine, living in Mexico but my identity is more with the U.S.... [I feel more connected] with the U.S. because I know more people and I have friends, but now that I live in Mexico, I feel more free.... [but] I would like to be with my family.

Jacinto makes it a point to emphasize that he is "fine" in Mexico, even though he feels he is "Mexican-American." But at the end, he reveals that his dislocation is not only about place, and where he lives now, but mainly about the family ties that have been severed due to the separation from his family and community.

There is a disconnect between national identity (as American) and state membership (as Mexican citizen). Xavier further explains that his citizenship does not match his nationality. He might be a Mexican citizen, but he feels like a U.S.American.

To be Mexican, well, I think that for me, it is just the place where you were born, and that is it, because right now [I am] Mexican, [but] I don't know much of the history of Mexico, I don't know anything about it, even though I would like to learn and know the history. I think it is in the history where you can identify why you are Mexican, the reasons and all that.

In Mexico, in comparison with the Mexican majority, and due to cultural and language differences, he realizes he is not Mexican but something else: he is Mexican-American, belonging to both worlds.

The return migrants' identity as Mexican-Americans reveals that they feel a rupture between their feelings of attachment to the U.S. and the reality that they are 
not able to go back legally. This rupture causes pain and anxiety as they must deal with the fact that they are being forced to live in Mexico due to the legal barriers against migrating to the U.S.

Gaspar explains the complex web of attachments:

The truth is that [I consider home to be] over there [in the U.S.] because I have more family members there [in the U.S.] than here in Mexico.... [I feel more identified] in Mexico, even though I liked over there [the U.S.] more, it is more fun than here.... [I feel more connected] in the U.S... [but I feel like I belong more] here in Mexico.

As the saying goes, "home is where the heart is," and for these migrants, home is mostly in the U.S., where their nuclear family resides. Thus, attachment to the nation is not only to an imagined space or community, but also with where connections were forged by family ties.

Eloisa also explains:

[I feel more identified] here in Mexico... I don't think I am [connected] to any place, because I lived for too long over there, and now I don't feel connected here, so neither place [I feel connected]... [I belong] in the U.S... [I identify as] Mexican... I feel part of both countries.

Ultimately, these return migrants want to return to the U.S.-the place where they feel much more comfortably culturally, but also the place where their family and friends live. But they are banned from returning for a period of time. Once they ban ends, they would still have to find a way to enter the U.S. legally. Yet, structurally, there are few means by which Mexican citizens can travel legally to the U.S.-as immigrants or non-immigrants.

If citizenship and belonging emerge from social relations, then aspiration is marked by past and present experiences. While in the U.S. the return migrants felt "at home" but legally marginalized; in Mexico they feel culturally excluded but legally entitled to rights. Yet they would prefer to return to their "home," where their family and friends await, and where they are familiar with the culture, the language, the history, and the institutions.

These aspirations for the future are not irrelevant, since they make the return migrants delay their incorporation into the social fabric of Mexico. Mercedes, for example, explains,

Right now I feel like [I am] in pause [mode], because I want to go [to the U.S.], and my family is always telling me to go, but because of the job I have I think about it and wonder, "What am I going to do in the U.S.?" I think about it and I stay [in Mexico] for the job. 
Being in "pause" mode prevents Mercedes, and other return migrants, from fully embracing their return, and working toward their incorporation into their new social milieu. In many ways, their experiences of marginality remain part of their reality in Mexico. In the U.S. they were legally marginalized, and in Mexico they feel culturally marginalized. This results in the postponement of plans (like those of Xavier, who has not returned to college because he is insecure about his command of Spanish) and even isolation (like Lorenzo's, who tends to only have friends at work who speak English and, like him, are return migrants). Illegality, in many ways, followed these migrants into Mexico even though they are no longer in a context of legal marginality. In Mexico they feel culturally and socially marginal because they identify culturally and socially as American.

\section{Exiled in the homeland}

The literature on the mobility of people across the globe has typically focused on global citizens or migrants. On one hand, research has focused on the "cosmopolitans" for whom international borders are of little consequence, and who travel temporarily to other countries; such research has tended to focus on the experiences of Global North citizens. On the other hand, scholars have also focused on the "migrants" who moved temporarily or permanently due to economic necessity or due to political circumstances, and this research has tended to focus on the experiences of Global South citizens migrating within the Global South or to the Global North. This research on migrants has also focused, for the most part, on the experiences of adult migrants. Recently, the migratory experiences of children have highlighted how their crossing experiences (Nazario, 2007) and their settlement patterns (Gonzalez, 2011; Abrego, 2011) are different from their adult counterparts. This line of research suggests that the duality of home/host society is more complicated when migrants move as children.

As this article has shown, return migrants who migrate as children become socialized and acculturated in the U.S. context, even while their legal status as unauthorized immigrants keeps them legally marginalized. Once they return to Mexico, however, they experience formal citizenship in Mexico as de jure citizens but not as de facto citizens, as they face social and cultural dislocation due to their limited knowledge of Mexican culture and history. As a result, they feel like "foreigners" in their own land. In the U.S. they adopt a "Mexican" identity due to their legal status; in Mexico they adopt an "Americanized" identity due to their cultural connections back in the U.S. Yet, in Mexico they come to feel like full citizens but feel ostracized as outsiders. 
Their return and the challenges these migrants have faced in Mexico highlight how these migrants represent the decoupling of the nation-state, as their stories reveal a sense of belonging to a nation that does not match their formal citizenship status. In addition, by highlighting their life stories, from migration to return migration, I showed how the state remains an important mechanism that shapes belonging. First, they are socialized within nation-states, but are rendered unauthorized, and are legally marginalized. Then, by ultimately limiting their opportunities, and shaping the return of these migrants, the state also shapes how people relate to both the U.S. and Mexico. These return migrants felt "trapped" in Mexico, unable to go to the place they identify as their "home." These stories also reveal the ways in which the experiences, labeling, and legal consequences of illegality can have longterm effects, even in the context of another country, where these migrants have full citizenship but feel like outcasts due to cultural differences. Finally, this paper sheds light on how, by shaping the mobility of these migrants-preventing them from legally moving to the place they see as their "home"-states ultimately shape mobility in an era of borderlessness.

The state, understood as the territorial boundaries of a country, is becoming increasingly porous due to regulated and unregulated flows across its borders; and the nation, understood as the community within the territorial state, is also becoming more fragmented, as the multiple communities within the boundaries of the state become increasingly multicultural and diverse. The grips of the nation-state are challenged daily not only externally, through disregard of the borders, but also internally, through separatist movements. In this context of a fragmented nationstate, identity, belonging, citizenship, and membership also become fractured. The process of integration among return migrants is a particularly useful case through which to study the fragmentation of nation-states, because these migrants have fragmented relationships with the nation-state in both countries. As the stories of these return migrants reveal, nation-state boundaries are both porous and flexible but also concrete and consequential.

\section{References}

Abrego, L. J. (2011). Legal consciousness of undocumented Latinos: fear and stigma as barriers to claims-caking for first - and 1.5- generation immigrants. Law and Society Review, 45(2), 337-370.

Anderson, J. (2015). 'Tagged as a criminal': narratives of deportation and return migration in a Mexico City call center. Latino Studies, 13(1), 8-27. Recuperado de http://www. palgrave-journals.com/doifinder/10.1057/lst.2014.72 
Andreas, P. \& Biersteker, T. J. (2003). The rebordering of North America: integration and exclusion in a new security context. New York and London: Routledge.

Appadurai, A. (1996). Modernity at large: cultural dimensions of globalization. Minneapolis: University of Minnesota Press.

Bosniak, L. (2000). Citizenship denationalized. Indiana Journal of Global Legal Studies, 7(2), 447-509.

Brown, W. (2010). Walled states, waning sovereignty. New York: Zone Books.

Brubaker, R. (1992). Citizenship and nationhood in France and Germany. Cambridge, Mass.: Harvard University Press.

Burke, P. \& Stets, J. E. (2000). Identity theory and social identity teory. Social Psychology Quarterly, 63(3), 224-237. Retrieved from http://www.jstor.org/stable/2695870 [Accessed: March 14, 2016].

Cassarino, J. P. (2004). Theorising return migration: the conceptual approach to return migrants revisited. International Journal on Multicultural Societies, 6(2), 253-279. Retrieved from http://www.researchgate.net/publication/26593895_The_Management_of_Multiculturalism_Coming_to_Terms_with_the_Multiplication_of_Experienced_Difference/file/72e7e52c6d7eab2a28.pdf\#page=60) [Accessed: December $10,2016]$.

Cobo, S. D., Giorguli, S. E. \& Alba, F. (2010). Occupational mobility among returned migrants in Latin America: a comparative analysis. The Annals of the American Academy of Political and Social Science, 630(1), 245-268. Retrieved from (http://ann.sagepub. com/cgi/doi/10.1177/0002716210368286) [Accessed: January 23, 2015].

Coutin, S. B. (2000). Legalizing moves: Salvadoran immigrants' struggle for U.S. residency. Ann Arbor: University of Michigan Press.

DeGenova, N. (2004). The legal production of Mexican/migrant 'illegality.' Latino Studies, 2, 160-185.

DeGenova, N. P. (2002). Migrant 'illegality' and deportability in everyday life. Annual Review of Anthropology, 31, 419-447.

Eschback, K., Hagan, J., Rodriguez, N., Hernandez-Leon, R \& Balley, S. (1999). Death at the border. IMR, 33(2), 430-454.

Gitter, S. R., Gitter, R. J. \& Southgate, D. (2008). The impact of return migration to Mexico. Estudios Económicos, 23(1), 3-23.

Glick-Schiller, N., Basch, L. \& Szanton-Blanc, C. (1994). From immigrants to transmigrants: theorizing transnational migration. Anthropological Quarterly, 68(1), 48-63.

Gonzalez, R. G. \& Chavez, L. R. (2012). 'Awakening to a nightmare': objectivity and illegality in the lives of undocumented 1.5 generation Latino immigrants in the United States. Current Anthropology, 53(3), 255-281.

Gonzalez, R. G. (2011). Learning to be illegal: undocumented youth and shifting legal context in transition to adulthood. American Sociological Review, 76(4), 602-619. 
Held, D. (1999). Democracy, the nation-state and the global system. In Waters, M. (ed.), Modernity critical concepts (vol. 4, After modernity). London: Ruotledge.

Levitt, P. (2001). The transnational villagers. Berkeley: University of California Press.

Marshall, T. H. (1964). Class, citizenship and social development. Chicago: University of Chicago Press.

Moya, E. M., Chávez Baray, S., Esparza del Villar, O. \& Castañeda, E. (2016). El síndrome de Ulises en inmigrantes económicos y políticos en México y Estados Unidos. Ehquidad International Journal of Welfare and Social Work Policies, 5, 11-50.

Nazario, S. (2007). Enrique's journey: the story of a boy's dangerous odyssey to reunite with his mother. New York: Random House LLC.

Ngai, M. M. (2005). Impossible subjects: illegal aliens and the making of modern America. Princeton: Princeton University Press.

Ohmae, K. (1994). The borderless world: power and strategy in the global marketplace. London: Harper Collins.

Ong, A. (1996). Cultural citizenship as subject-making: immigrants negotiate racial and cultural boundaries in the United States. Current Anthropology, 37(5), 737-751.

Rosaldo, R. (1994). Cultural citizenship and educational democracy. Cultural Anthropology, 9(3), 402-411.

Rosas, G. (2006). The managed violences of the borderlands: treacherous geographies, policeability, and the politics of race. Latino Studies, 4, 401-418.

Rumbaut, R. (2004). Ages, life stages, and generational cohorts: decomposing the immigrant first and second generations in the United States. IMR, 38(3), 1160-1205.

Sarabia, H. (2012). Perpetual illegality: results of border enforcement and policies for Mexican undocumented migrants in the United States. Analyses of Social Issues and Public Policy, 12(1), 49-67.

Sarabia, H. (2014). Global South cosmopolitans: the opening and closing of the USA-Mexico border for Mexican tourists. Ethnic and Racial Studies, 38(2), 227-242.

Sassen, S. (2003). Global cities and survival circuits. In Ehrenreich, B. \& Hochschild, A. R. (eds.), Global woman: nannies, maids, and sex workers in the new economy. New York: Metropolitan Books.

Suárez, M. J. (2016). De ida y de vuelta: el impacto de la política migratoria estadounidense en México y su población retornada. Carta Económica Regional, 114, 66-91.

Truax, E. (2015). Dreamers:an immigrant generation's fight for their American dream. Boston, Mass.: Beacon Press.

Ullmann, S. H., Goldman, N. \& Massey, D. S. (2011). Healthier before they migrate, less healthy when they return? The health of returned migrants in Mexico. Social Science \& Medicine, 73(3), 421-428.

Waldinger, R. (2008). Between 'here' and 'there': immigrant cross-border activities and loyalties. The International Migration Review, 42, 3-29.

Yuval-Davis, N. (1997). Women, citizenship and difference. Feminist Review, 57, 4-27. 